\title{
THE INFLUENCE OF PARTICIPATORY LEADERSHIP AND COMMUNICATION ON INTRINSIC AND EXTRINSIC MOTIVATION AND ITS IMPACT ON THE PERFORMANCE OF BUREAU OF GOODS AND SERVICES PROCUREMENT OF ACEH REGIONAL SECRETARIAT
}

\author{
Andriansyah, Mukhlis and Said Musnadi \\ Management Department, Universitas Syiah Kuala, Indonesia \\ http://doi.org/10.35409/IJBMER.2021.3268
}

\begin{abstract}
This study aims to determine the influence of leadership and communication on intrinsic and extrinsic motivation and its impact on the performance of the bureau of goods and services procurement of Aceh regional secretariat.This study used a census sampling technique and provided 131 respondents. The result shows that participatory leadership style significantly affects intrinsic motivation, communication significantly affects intrinsic motivation, participatory leadership style significantly affects extrinsic motivation, communication significantly affects extrinsic motivation, participatory leadership styles significantly affects employee performance, communication significantly affects employee performance, Intrinsic motivation significantly affects employee performance, and Extrinsic motivation significantly affects employee performance. These findings reveal that the research model is acceptable to be a model that can improve employee performance in the Goods and Services Procurement Bureau in the Aceh regional secretariat. Improvements in participatory leadership style and strengthening communication can increase intrinsic motivation and extrinsic motivation so that they have an impact on employee performance. Further researchers are expected to develop this research model by adding organization citizenship behavior and competencies to further complement the model.
\end{abstract}

Keyword: Participatory Leadership Style, Communication, Intrinsic Motivation, Extrinsic Motivation, and Employee Performance.

\section{INTRODUCTION}

The implementation of activities in the organization is carried out by humans who act as actors in the organization so that the organizational performance is automatically influenced by human behavior in the organization. Therefore, increasing quality human resources is intended so that an organization can unify perceptions or perspectives between employees and leaders/superiors in order to achieve organizational goals, among others by providing work motivation, guidance, direction, and good coordination in work by a person. leadership to subordinates.

Organizational goals will be achieved through positive performance from employees, otherwise, the organization will face obstacles in achieving goals when the performance of employees is ineffective, in the sense that it cannot meet the demands of the job that the 


\section{International Journal of Business Management and Economic Review}

Vol. 4, No. 03; 2021

ISSN: 2581-4664

organization wants. For organizational leaders, employee performance is very important because it is a benchmark for success in managing the organization they lead. So, performance is a central factor for management's work in managing the organization. According to (Setiawan \& Waridin, 2006), employee performance is the result of work performance determined by the organization. The success of an organization is greatly influenced by the performance of its employees.

In order to improve the Bureau of Goods and Services Procurement, Aceh Regional Secretariat as one of the Government institution in Aceh Province, Indonesia, is supported by Electronic Procurement Services (LPSE), which is an information technology management service to facilitate the implementation of electronic procurement of goods/services. UKPBJ / Procurement Officials at Ministries / Institutions / Regional Devices that do not have Electronic Procurement Services can use the Electronic Procurement Service facility closest to their domicile to carry out procurement electronically. In addition to facilitating UKPBJ / Procurement Officials in carrying out the procurement of goods/services electronically, Electronic Procurement Services also serves the registration of goods and services providers who are domiciled in the relevant Electronic Procurement Service work area.

Electronic procurement of goods/services will increase transparency and accountability, increase market access and fair business competition, improve the level of efficiency of the procurement process, support monitoring, and auditing processes, and meet the need for realtime access to information in order to realize clean and good government in goods procurement. government services.

The low performance of the employees of the Bureau of Goods and Services Procurement in Aceh Regional Secretariat is not just an employee's fault, but also has to be seen from whether the company or organization has responded to complaints submitted by employees. Because without balancing the interests of the two parties, it is certain that the goals of the organization will never be achieved.

One of the causes of low employee performance is the low motivation of employees to work on employee performance. In order to increase the work motivation of employees at the Bureau of Goods and Services Procurement, the leaders needs to provide work motivation to employees through increased timeliness in completing work in the form of providing awareness to employees of the importance of work discipline in achieving organizational goals.

Motivation is the willingness to exert a high level of effort towards company goals, which is conditioned by the ability of that effort to meet several individual needs (Sakara \& Alhassan, 2014). Needs can be physical, biological, and socioeconomic. However, what the more important is the existence of social-psychological needs, such as appreciation, recognition, safety, security protection, and social security. Work motivation can provide energy that can mobilize all existing potentials, create high and noble desires and increase togetherness. Each party works according to established rules or standards with mutual respect, mutual need, mutual understanding, and respect for each other's rights and obligations in the entire work process.

Another factor that also influences motivation and job satisfaction is the leadership style that the superior has towards his subordinates. Preliminary observations made by researchers at the Bureau of Goods and Services Procurement in Aceh Regional Secretariat showed that the leader still did not appreciate their subordinates, they were only used as objects of work achievement and did not pay attention to the level of employee welfare. 


\section{International Journal of Business Management and Economic Review}

Vol. 4, No. 03; 2021

ISSN: 2581-4664

Then other factors that can affect employee performance, one of which is the communication factor carried out by employees. Communication in the world of work is a very important factor for an organization because, in an organization, communication is one of the keys to organizational success. If communication does not go well, there will often be misunderstandings between divisions/units or interpersonal within the company, or often referred to as missed communication. Interpersonal relations between employees is a company way to strengthen interpersonal relationships between employees, so that company goals can be achieved.

\section{LITERATURE REVIEW}

Employee Performance

The definition of performance according to (Timpe, 2012), performance is the level of achievement of a person or employee in an organization or company that can increase productivity. According to (Siddiqui, 2014) employee performance is a success that can be achieved by individuals in doing their work, where the measure of success achieved by an individual cannot be equated with other individuals. The success achieved by an individual is based on the prevailing size and adapted to the type of work.

Employee performance refers to a person's achievement as measured by the standards and criteria set by the company. Management to achieve high human resource performance is intended to improve the company as a whole (Osabiya \& Joseph, 2015). According to (Robins \& Coulter, 2012) performance is a combination of behavior with the achievement of what is expected and the choice or part of the job requirements that exist for each individual in the organization. (Obiwuru, Okwu, Akpa, \& Nwankwere, 2011) tends to use the word "performance" in referring to "work performance".

\section{Work Motivation}

Motivation comes from the Latin word "movere" which means encouragement, desire, cause, or reason for someone doing something. Meanwhile, according to (Handoko, 2008), motivation is defined as a situation in a person's personality that encourages an individual's desire to carry out certain activities for a purpose.According to (Mathis \& Jackson, 2011), motivation is a desire in a person that causes that person to take action. Meanwhile, (Rivai \& Sagala, 2014) argues that motivation is a series of attitudes and values that influence individuals to achieve specific things according to individual goals. According to (Robins \& Coulter, 2012), motivation is the willingness to make high-level efforts to achieve organizational goals that are conditioned by the ability of the business to satisfy the needs of a number of individuals.

Intrinsic motivation is a condition that is needed by all people who are innocent from within themselves. It is needed every day to live life, help others, lead a group of people, and to achieve the desired goals (Robbins, Coulter, \& Cenzo, 2019). Motivation comes from the word "movere" (Latin), which means to encourage or move (Robbins et al., 2019).Motivation will encourage an employee to make his wishes come true, this is what is meant by motivation. Selfmotivation comes from an employee himself, not because someone else tells an employee to do something. Because of ambition and desire, a person will be moved to be more than he is today. Many people have a big desire and ambition to get something. They just keep silent and contemplate afraid of what will happen.Extrinsic motivation is the motivation that comes from 


\section{International Journal of Business Management and Economic Review}

Vol. 4, No. 03; 2021

ISSN: 2581-4664

outside or from other people. Motivation does look easy but someone will rise with motivation from other people who are smarter or older than them. But motivation can also come from people who are younger or the same age as that person.

\section{Leadership Style}

A person will be able to influence the performance of an organization, depending on how he carries out leadership activities in it. Through the right leadership system, it will be able to lift companies that are collapsing or waiting for time to stop operating to recover and improve their performance. The various leadership styles that have been applied by some of the leaders of the companies can develop in their time. Mary ann Byrnes as CEO of Corsair Communications held on to a group of satisfied employees where they were accustomed to doing work in terms of the type of work ten percent a day.

Leadership style is a pattern of behavior shown by leaders in influencing others(Luthans, 2013). This pattern of behavior can be influenced by several factors such as values, assumptions, perceptions made by experts based on the assumption that certain patterns of behavior in influencing subordinates determine the effectiveness of the leader. Leadership is the influence between individuals that is exercised in certain situations and is directed through the communication process towards the achievement of one or more specific goals. Leadership concerns the process of deliberate social influence carried out by a person on another to structure activities and influence within a group or organization.

\section{Communication}

According to (Effendy, 2013), if two people are involved in communication, for example in the form of a conversation, then communication will occur or take place as long as there is a similarity in meaning about what is being said. Further stated by (Mangkunegara, 2013), Communication can be defined as the process of transferring information, ideas, understanding from one person to another in the hope that the other person can interpret it according to the intended purpose. Meanwhile, Canggara (2011) stated that communication is a process in which two or more people form or exchange information with each other which in turn will arrive at a deep mutual understanding.

\section{Previous Research Review}

Research conducted by (Hidayat, Lubis, \& Majid, 2019)revealed that participatory leadership style has an influence on improving employee performance. Then the research conducted by (Bahagia, 2017) stated that the work motivation of employees has an influence in improving employee performance. Meanwhile, research conducted by (Bintar, Yunus, \& Musnadi, 2020) explained that the communication carried out by members of the police at the Pidie Police can improve the performance of members and have implications for improving the organizational performance of the Pidie Police Traffic Unit.

\section{Research Hypothesis}

From the discussion above, the authors formulate the hypothesis for this research as follows.

H1. participatory leadership style significantly affects intrinsic motivation

H2. communicationsignificantly affects intrinsic motivation 
Vol. 4, No. 03; 2021

ISSN: 2581-4664

H3. participatory leadership style significantly affects extrinsic motivation

H4. communicationsignificantly affects extrinsic motivation

H5. participatory leadership stylesignificantly affects employee performance

H6. Communication significantly affects employee performance

H7. Intrinsic motivation significantly affects employee performance

H8. Extrinsic motivation significantly affects employee performance

\section{METHOD}

\section{Location and Object of Research}

The location of this research was carried out at the Bureau of Goods and Services Procurement, in the Aceh Regional Secretariat, one of the government institution in Indonesia. The objects of research are participatory leadership style, communication, intrinsic and extrinsic motivation, and the employee performance.

\section{Data Analysis Tool}

Data analysis tools to test respondents' perceptions used descriptive tests based on the mean value of each variable, with the assumption that if the mean value is $<4$, it is perceived as poorly and if the mean value is $\geq 4$, it is well perceived by the respondent. The data collected was analyzed using structural equation modeling (SEM), which is a set of statistical techniques that allow testing a series of relatively complex relationships simultaneously (Ferdinand, 2014).The appearance of a complex model implies that in reality the management decision-making process is a complex process or is a multidimensional process with various hierarchical patterns of causality. Therefore we need a model as well as an analytical tool that is able to accommodate this multidimensional research.

\section{RESULT}

The data processedthru the full model SEM stage was carried out by performing a suitability test and statistical test. The results are shown in the following Figure: 


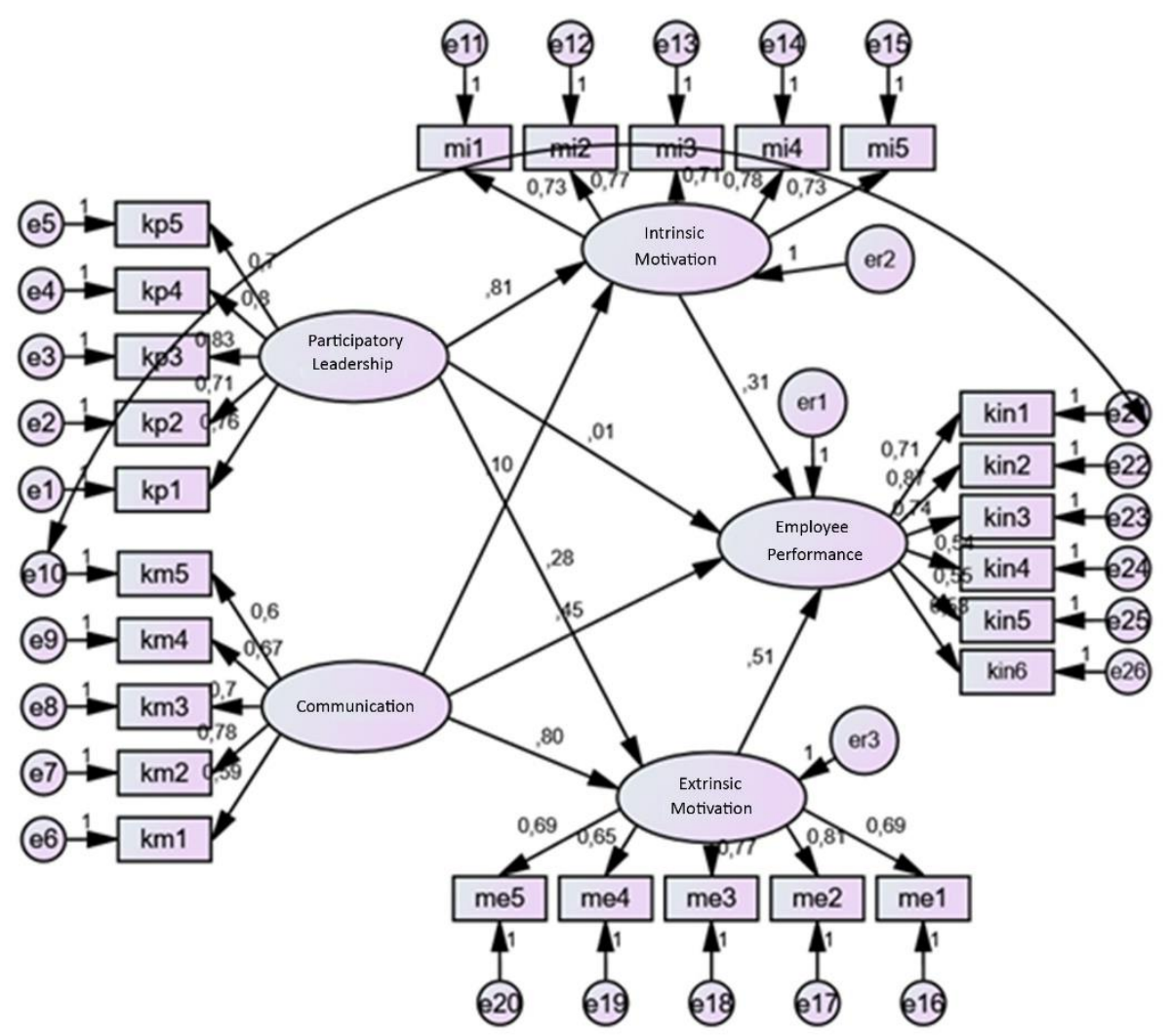

Figure 1. SEM Result

\section{H1 : The Influence of Participatory Leadership on Intrinsic Motivation}

The testing for the influence of participatory leadership on employee intrinsic motivation provides a Critical Ratio (CR) value 10.783 and a probability (p-value) 0.000 . Those two values mean the test result meets the requirements to accept H2, namely the CR value $>1.96$ and the pvalue $<0.05$. The testing also provides the coefficient value of 0.808 indicates that if there is an increase in participatory leadership of 1 unit, it will affect the increase in intrinsic motivation by 0.808 units.

\section{H2 : The Influence of Communication on the Intrinsic Motivation}

The testing for the influence of employee communication on employee intrinsic motivationprovides a $C R$ value 6.341 and a p-value 0.000 . Those two values mean the test result meets the requirements to accept $\mathrm{H} 3$, namely the $\mathrm{CR}$ value $>1.96$ and the $\mathrm{p}$-value $<0.05$. The testing also provides the coefficient value of 0.103 indicates that if there is an increase in communication by 1 unit, it will affect the increase in intrinsic motivation by 0.103 units.

\section{H3 : The Influence of Participatory Leadership on Extrinsic Motivation}

The testing for the influence of participatory leadership on employee extrinsic motivation provides a $\mathrm{CR}$ value 3.613 and a p-value 0.000. Those two values mean the test result meets the requirements to accept $\mathrm{H} 4$, namely the $\mathrm{CR}$ value $>1.96$ and the $\mathrm{p}$-value $<0.05$. The testing also 


\section{International Journal of Business Management and Economic Review}

Vol. 4, No. 03; 2021

ISSN: 2581-4664

provides the coefficient value of 0.285 indicates that if there is an increase in participatory leadership of 1 unit, it will influence the increase in extrinsic motivation by 0.285 units.

\section{H4 : The Influence of Communication on Extrinsic Motivation}

The testing for the influence of communication on employee extrinsic motivation provides a CR value 4.733 and a p-value 0.000 . Those two values mean the test result meets the requirements to accept $\mathrm{H} 5$, namely the $\mathrm{CR}$ value $>1.96$ and the $\mathrm{p}$-value $<0.05$. The testing also provides the coefficient value of 0.795 indicates that if there is an increase in communication by 1 unit, it will affect the increase in extrinsic motivation by 0.795 units.

\section{H5 : The Influence of Participatory Leadership on Employee Performance}

The testing for the influence of participatory leadership on employee performance provides a CR value 4.039 and a p-value 0.000 . Those two values mean the test result meets the requirements to accept $\mathrm{H} 6$, namely the $\mathrm{CR}$ value $>1.96$ and the p-value $<0.05$ Thetesting also provides the coefficient value of 0.010 indicates that if there is an increase in participatory leadership by 1 unit, it will have an effect on the increase in employee performance by 0.010 units.

\section{H6 : The Influence of Communication on Employee Performance}

The testing for the influence of communication on employee performance shows a CR value of 5.572 and a probability of 0.000 . Those two values mean the test result meets the requirements to acceptH7, namely the CR value $>1.96$ and the p-value $<0.05$. Thetesting also provides the coefficient value of 0.453 indicates that if there is an increase in communication by 1 unit, it will influence the increase in employee performance by 0.453 units.

\section{H7 : The Influence of Intrinsic Motivation on Employee Performance}

The testing for the influence of intrinsic motivation on employee performance provides a $\mathrm{CR}$ value 3.416 and a probability 0.000 . Those two values mean the test result meets the requirements to accept $\mathrm{H} 8$, namely the $\mathrm{CR}$ value $>1.96$ and the $\mathrm{p}$-value $<0.05$. Thetesting also provides the coefficient value of 0.306 indicates that if there is an increase in the intrinsic motivation of 1 unit, it will affect the increase in employee performance by 0.306 units.

\section{H8 : The Influence of Extrinsic Motivation on Employee Performance}

The testing for the influence of extrinsic motivation on employee performance shows a CR value of 4.677 and a probability of 0.000 . Those two values mean the test result meets the requirements to acceptH9, namely the $\mathrm{CR}$ value $>1.96$ and the $\mathrm{p}$-value $<0.05$. Thetesting also provides the coefficient value of 0.505 indicates that if there is an increase in extrinsic motivation of 1 unit will affect the increase in employee performance by 0.505 units.

\section{CONCLUSION}

The result shows thatparticipatory leadership style significantly affects intrinsic motivation, communication significantly affects intrinsic motivation, participatory leadership style significantly affects extrinsic motivation, communication significantly affects extrinsic motivation, participatory leadership styles significantly affects employee performance, communication significantly affects employee performance, Intrinsic motivation significantly 


\section{International Journal of Business Management and Economic Review}

Vol. 4, No. 03; 2021

ISSN: 2581-4664

affects employee performance, and Extrinsic motivation significantly affects employee performance.These findings reveal that the research model is acceptable. This means that this model is proven to be a model that can improve employee performance in the Goods and Services Procurement Bureau in the Aceh regional secretariat. Improvements in participatory leadership style and strengthening communication can increase intrinsic motivation and extrinsic motivation so that they have an impact on employee performance. This proven model can be an academic reference for the next researcher's morning, and also for practitioners, especially the Bureau of goods and services procurement of Aceh Regional Secretariat, to set strategies for improving employee performance. Further researchers are expected to develop this research model by adding organization citizenship behavior and competencies to further complement the model.

Several recommendations are provided.In order to increase work motivation both intrinsically and extrinsically and the performance of the employees of the Bureau of Goods and Services Procurement, Aceh Regional Secretariat based on participatory leadership variables, what needs to be paid attention is that the leadership must always be open to any problems faced by subordinates to achieve a joint solution so that any problems that arise can be resolved in a transparent and responsible manner.Then to increase intrinsic and extrinsic work motivation and employee performance based on communication variables, it is recommended that the leaders can establish good communication with all subordinates, and also the leader must be able to maintain communication to keep it smooth without any obstacles.To increase intrinsic and extrinsic work motivation, what needs to be paid attention to is that the leadership must give awards to employees who excel so that it will encourage other employees to increase motivation at work and also need encouragement from family to relevant employees such as parents, wives, husbands, and children in carrying out their work. And, In order to improve employee performance, what needs to be paid attention to and is carried out is that employees must be able to carry out work without the help of other people, in order to create better work results, without having to involve other people in helping to complete work.

\section{REFERENCES}

Bahagia, S. (2017). Pengaruh Kompetensi, Reward, Dan Motivasi Pegawai Terhadap Kinerja Pegawai Serta Dampaknya Pada Pengembangan Karir Di Dinas Sosial Aceh. Syiah Kuala University.

Bintar, R., Yunus, M., \& Musnadi, S. (2020). The Effect Of Communication, Education, And Trust On Member Performance And Its Implications On The Organizational Performance :Study In Pidie Polantas. International Journal of Business Management and Economic Review, 3(1), 235-248. https://doi.org/http://doi.org/10.35409/IJBMER.2020.3153

Effendy, O. U. (2013). Ilmu Komunikasi Teori Dan Praktek. Bandung: Remaja Rosdakarya.

Ferdinand, A. (2014). Metode Penelitian Manajemen (Edisi 5). Semarang: Universitas Diponegoro.

Handoko, H. (2008). Manajemen personalia dan Sumberdaya Manusia (2nd ed.). Yogyakarta: BPFE.

Hidayat, S., Lubis, A. R., \& Majid, M. S. A. (2019). Pengaruh Gaya Kepemimpinan, Kerjasama Tim Dan Kompensasi Terhadap Kinerja Karyawan Melalui Kepuasan Kerja Karyawan 


\section{International Journal of Business Management and Economic Review}

Vol. 4, No. $03 ; 2021$

ISSN: 2581-4664

Pada PT. Dunia Barusa Banda Aceh. Jurnal Perspektif Ekonomi Darussalam, 5(1), 86100. https://doi.org/https://doi.org/10.24815/jped.v5i1.14088

Luthans, F. (2013). Organizational Behavior An Evidence-Based Approach (8th ed.). New York: Mc Graw Hill.

Mangkunegara, A. P. (2013). Manajemen Sumber Daya Manusia Perusahaan. Bandung: Remaja Rosdakarya.

Mathis, R. L., \& Jackson, J. H. (2011). Human Resource Management: Essential Perspectives (6th ed.). USA: Cengage Learning.

Obiwuru, T. C., Okwu, A. T., Akpa, V., \& Nwankwere, I. A. (2011). Effects of leadership style on organizational performance: A survey of selected small scale enterprises in IKOSIKETU Council development area of Lagos state, Nigeria. Australian Journal of Business and Management Research, 1(7), 100-111.

Osabiya, \& Joseph, B. (2015). The effect of employees motivation on organizational performance. Journal of Public Administration and Policy Research, 7(4), 62-75. https://doi.org/10.5897/JPAPR2014.0300

Rivai, V., \& Sagala, E. J. (2014). Manajemen Sumber Daya Manusia untuk Perusahaan: Dari Teori ke Praktik (3rd ed.). Jakarta: Rajawali Pers.

Robbins, S. P., Coulter, M. A., \& Cenzo, D. A. De. (2019). Fundamentals of Management (11th ed.). London: Pearson.

Robins, S. P., \& Coulter, M. (2012). Management (11th Ed). In Prentice Hall. https://doi.org/10.1002/1521-3773(20010316)40:6<9823::AID-ANIE9823>3.3.CO;2-C

Sakara, A., \& Alhassan, F. (2014). An Assessment Of Sales Promotion As Effective Tool For Customer Retention In Telecommunications Industry Of Ghana (A Case Study Of University For Development Studies, Ghana). International Journal of Economics, Commerce and Management, II(10), 1-22.

Setiawan, B., \& Waridin. (2006). Pengaruh Disiplin Kerja Karyawan dan Budaya Organisasi terhadap Kinerja di Divisi Radiologi RSUP Dokter Kariadi Semarang. Jurnal Riset Bisnis Indonesia, 2(2), 181-250.

Siddiqui, M. N. (2014). Success of an Organization is a result of Employees Performance. Advances in Social Sciences Research Journal, 1(4), 179-201. https://doi.org/10.14738/assrj.14.280

Timpe, A. D. (2012). Seri Manajemen Sumber Daya Manusia (A. D. Ti, Ed.). Jakarta: PT Elex Media Komputindo. 